ISSN : 2302 - 7517, Vol. 03, No. 03

\title{
POLA ADAPTASI EKOLOGI DAN STRATEGI NAFKAH RUMAHTANGGA DI DESA PANGUMBAHAN
}

\author{
Pattern of Ecological Adaptation and Household Livelihood Strategies in Rural Pangumbahan
}

Ahmad Choibar Tridakusumah*), Mira Elfina, Dyah Ita Mardiyaningsih, Jepri Pioke, dan Sahrain Bumulo

Program Studi Sosiologi Pedesaan Fakultas Ekologi Manusia, Sekolah Pascasarjana IPB

\begin{abstract}
Pangumbahan village has a community social dynamics in the presence of macro-scale economic activity in the form of concession palm plantations as well as new economic alternatives to the industrial development of this ecotourism. This study goal is trying to see how far the pattern of ecological adaptation and structure of households living Pangumbahan village communities that exist today. This study used a qualitative approach and supported with quantitative approach. The results showed that the pattern of ecological adaptation Pangumbahan villagers among others determined by the existence of the plantation concession and conservation of sea turtles as limiting the presence of a village community culture Pangumbahan. Limitations of natural resources, human and financial force households to undertake a variety of strategies to survive. Strategies conducted household income villagers Pangumbahan be varied. In one household can apply two or more types of livelihood strategies.
\end{abstract}

Keywords: ecological adaptation pattern, livelihood strategies, social dynamics

\begin{abstract}
ABSTRAK
Desa Pangumbahan memiliki dinamika sosial masyarakat dengan adanya kegiatan ekonomi skala makro dalam bentuk konsesi perkebunan kelapa serta alternatif ekonomi baru untuk pengembangan industri ekowisata ini. Tujuan penelitian ini mencoba untuk melihat seberapa jauh pola adaptasi ekologi dan struktur rumah tangga yang tinggal dalam masyarakat desa Pangumbahan yang ada saat ini. Penelitian ini menggunakan pendekatan kualitatif dan didukung dengan pendekatan kuantitatif. Hasil penelitian menunjukkan bahwa pola adaptasi ekologi Pangumbahan desa antara lain ditentukan oleh adanya konsesi perkebunan dan konservasi penyu yang membatasi kehadiran budaya masyarakat desa Pangumbahan. Keterbatasan sumber daya alam, manusia dan rumah tangga kekuatan keuangan untuk melakukan berbagai strategi untuk bertahan hidup. Strategi yang dilakukan warga desa pendapatan rumah tangga Pangumbahan bervariasi. Dalam satu rumah tangga dapat menerapkan dua atau lebih jenis strategi penghidupan.
\end{abstract}

Kata kunci: dinamika sosial, pola adaptasi ekologi, strategi mata pencaharian

\section{PENDAHULUAN}

\section{Latar Belakang}

Desa Pangumbahan berasal dari kata "kumbah" atau cuci, dimana menurut tokoh masyarakat setempat diambil dari sebuah batu tempat mencuci kaki orang suci pada jaman dahulumenurutcerita sunda. Desa pangumbahanmerupakan salah satu desa di Kecamatan Ciracap yang merupakan pemekaran dari Desa Gunung Batu dengan luas wilayah 1.916 hektar terdiri dari 4 dusun, yaitu Dusun Ciburial, Waluran, Jaringao dan Pangumbahan, terbagi dalam 9 Rukun Warga dan 28 Rukun Tetangga. Jumlah penduduk Desa Pangumbahan berdasarkan data dari Monografi Desa tahun 2013 sebanyak 4.431 jiwa yang terdiri dari 2.210 perempuan dan 2.221 laki-laki. Penduduk didominasi oleh dua etnis, yaitu etnis Sunda yang merupakan penduduk asli dan etnis Jawa sebagai pendatang yang dibawa oleh penjajah Belanda pada abad 19 sebagai pekerja perkebunan.

Berdasarkan tipe ekologi, Desa Pangumbuhan terdiri dari kawasan pesisir, lahan basah/persawahan dan lahan kering. Rumahtangga masyarakat Desa Pangumbahan mengembangkan sistem matapencaharian berdasarkan ketersediaan ketiga tipe ekologi tersebut. Sesuai dengan tipe ekologi sebagian besar penduduk mempunyai mata pencaharian sebagai petani, buruh 
tani, nelayan, pegawai, penjaga penginapan, tukang ojeg, buruh bangunan, sebagain kecil bergerak di bidang perdagangan dan jenis pekerjaan lainnya.

Namun seiring dengan semakin bertambahnya jumlah penduduk, kemudahan akses transportasi dan komunikasi, perubahan penggunaan lahan dan munculnya alternatif sumber nafkah baru,mendorong munculnya pola adaptasi dan struktur nafkah baru pada rumahtangga masyarakat. Makalah ini mencoba untuk melihat sejauhmana pola adaptasi ekologi dan struktur nafkah rumahtangga masyarakat Desa Pangumbahan yang ada saat ini.

\section{Tujuan}

Tujuan pertama dari makalah ini adalah mengidentifikasi pola-pola adaptasi yang dilakukan oleh rumahtangga masyarakat Desa Pangumbahan sesuai dengan ketersediaan tipe ekologinya. Hal ini perlu dilakukan karena kondisi ekologi yang berada di Desa Pangumbahan mengalami perubahan seiring perubahan pola pengelolaan kawasan, pemanfaatan yang telah dilakukan dan perubahan masyarakat secara sosial ekonominya. Belum lagi pengembangan aktivitas ekonomi baru yang menjadi bagian dari program pembangunan yang didorong oleh pemerintah maupun masuknya investor untuk memanfaatkan potensi sumberdaya alam yang ada di Desa Pangumbahan.

Tujuan kedua dari makalah ini adalah mengidentifikasi pilihan strategi nafkah rumahtangga masyarakat Desa Pangumbahan. Pilihan strategi nafkah sebagai bagian dari sistem penghidupan masyarakat, sangat berkaitan dengan pola-pola adaptasi ekologi yang dilakukan. Perubahan pada kondisi ekologi mendorong pada perubahan pola adaptasi ekologi yang juga merupakan bagian dari bentukbentuk strategi nafkah yang dilakukan rumahtangga. Untuk melihat strategi nafkah yang dilakukan rumahtangga masyarakat, makalah ini menggunakan tipe strategi nafkah dari Scoones (1998:9) dalam Dharmawan (2001 : 90), yaitu (1) intensifikasi atau diversifikasi pertanian; (2) pola nafkah ganda (keragaman nafkah); dan (3) migrasi.

\section{METODOLOGI}

Kajian ini dilaksanakan pada Bulan November 2014 selama 5 hari di Desa Pangumbahan Kecamatan Ciracap Kabupaten Sukabumi.Desa Pangumbahan dipilih karena mewakili masyarakat pedesaan yang syarat dengan dinamika sosial baik sebelum maupun setelah kemerdekaan. Menjadi menarik untuk mempelajari dinamika sosial masyarakatnya dengan adanya aktivitas ekonomi skala makro dalam bentuk HGU perkebunan kepala. Selain itu, alternatif ekonomi baru dengan perkembangan industri pariwisata memebrikan nuansa baru pada dinamika sosial tersebut termasuk sistem penghidupan masyarakatnya.

Pendekatan kualitatif dengan strategi studi kasus kemudian dipilih untuk memaksimalkan mendapatkan data dan informasi dalam waktu yang relatif singkat. Metode wawancara mendalam dan observasi langsung kepada beberapa rumahtangga masyarakat sehingga diperoleh gambaran mengenai sistem penghidupan rumahtangga masyarakat dan pilihan strategi nafkah yang dilakukan. Diskusi kelompok dengan aparat desa dan studi literatur dari dokumen yang dimiliki di tingkat desa memberikan tambahan data dan informasi yang mendukung hasil wawancara dan observasi langsung di tingkat rumahtangga. Untuk mendapatkan data kuantitatif di tingkat rumahtangga, terutama rumahtangga tani, kajian ini juga menggunakan metode mini survey pada tujuh rumahtangga yang terutama untuk mendapatkan informasi mengenai luas kepemilikan lahan.

\section{PEMBAHASAN}

\section{Pola Adaptasi Ekologi}

\section{Petani: labil secara sosial-ekonomi}

Secara topografi, Pangumbahan merupakan salah satu desa yang terletak di teras pantai selatan Jawa dengan tekstur dominan dataran rendah dengan beberapa kawasan yang cenderung berbukit. Seperti kawasan pesisir pada umumnya, mata pencaharian masyarakat lokal Pangumbahan bergerak pada sektor kelautan yang diimbangi oleh sektor pertanian. Pada sektor kelautan, selain memunculkan profesi nelayan, juga berkembang pesat sektor pariwisata. Sedangkan pada sektor pertanian, yang menjadi andalan masyarakat lokal yakni persawahan dan perkebunan. Jika dipetakan berdasarkan tempat tinggal, masyarakat yang tinggal di kawasan pesisir Pangumbahan umumnya berprofesi sebagai nelayan dan penyedia jasa pariwisata. Sedangkan masyarakat yang tempat tinggalnya agak menjorok kedalam (memiliki radius yang cukup jauh dari laut), umumnya berprofesi sebagai petani dan buruh tani.

Walaupun posisi geografi wilayah Pangumbahan merupakan kawasan pesisir, namun geliat sektor pertanian juga menjadi salah satu indikator yang menentukan struktur sosial ekonomi masyarakatnya. Komoditi sektor pertanian yang ada antara lain berupa kelapa, tanaman padi, semangka dan kacang-kacangan. Dari keempat komoditi tersebut, padi (beras) menjadi komoditi yang paling diandalkan masayarakat lokal khususnya para petani. Walaupun luas lahan persawahan terbatas, namun beras selain sebagai sumber pangan utama, juga dapat dikonversi menjadi sumber finansial yang cukup menjanjikan untuk keberlangsungan hidup rumah tangga petani lokal.

Akan tetapi, meski beras merupakan komoditi andalan petani lokal Pangumbahan, namun sistem produksinya boleh dibilang masih bersifat konvensional. Hampir tidak ada sumber air yang intens mengairi setiap petakan sawah yang ada. Perangkat yang digunakan untuk mengolah 
lahan becek tersebut umumnya juga masih menggunakan perangkat yang sederhana. Memang penggunaan teknologi pertanian moderen sudah ada, namun penggunaannya belum bersifat masif. Akibatnya sawah-sawah yang ada di Pangumbahan dapat dikategorikan sebagai sawah tadah hujan yang dalam hal ini belum mengalami intensifikasi yang berarti. Jika kebanyakan sawah produktif mengalami musim tanam sebanyak 3 kali dalam setahun, maka sawah di Pangumbahan hanya mengalami 2 kali musim tanam dalam setahun. Hal tersebut juga masih akan dipengaruhi lagi oleh faktor iklim, seperti musim penghujan dan kemarau. Walaupun demikian berdasarkan kalender pertanian petani lokal, mereka pada umumnya menjalani musim tanam pada kisaran bulan Februari-Maret dan November-Desember.

Upaya ekstensifikasi lahan barulah dilakukan pada tahun 2014. Upaya tersebut mencuat seiring mulai eksisnya keberadaan kelompok-kelompok tani di Pangumbahan. Melalui gerakan kelompok-kelompok tani muncul inisiatif untuk melakukan ekstensifikasi lahan pertanian. Melalui kerjasama dengan pihak pemerintah setempat, lahan berbukit seluas \pm 50 ha kemudian disulap menjadi kawasan persawahan. Walaupun produktivitasnya tidak jauh berbeda dengan lahan persawahan dataran rendah yang sudah ada, paling tidak perluasan kawasan persawahan tersebut dapat mengurangi resiko instabilitas kondisi sosial-ekonomi petani. Selain itu, kelompok-kelompok tani juga mulai aktif melakukan manejerial hasil panen secara kolektif agar dapat mencukupi kebutuhan pangan hingga panen berikutnya. Pola ekspansi persawahan seperti ini sudah sejak zaman kolonial dilakukan, namun berjalan lambat, setengah-setengah, coba-coba dan maju-mundur sehingga tidak signifikan meningkatkan kesejahteraan petani seiring tekanan penduduk (Geertz, 1983).

Belum adanya intensifikasi sistem persawahan membuat produksi beras yang dihasilkan petani sawah cenderung terbatas.Hal ini membuat beras yang notabenenya sebagai komoditi utama justru mengalami ketimpangan pemanfaatannya. Terbatasnya produksi beras membuat orientasinya lebih dominan pada aspek konsumsi ketimbang distribusi. Sehingganya, masyarakat terkadang diperhadapkan pada situasi-situasi genting, apakah harus menjual beras atau menyimpannya untuk mengganjal perut hingga panen berikutnya tiba. Hal ini menjadi kian pelik mengingat semakin kompleksnya tuntutan kebutuhan yang mau tidak mau harus dipenuhi. Di sisi lain, jumlah anggota keluarga petani setiap tahunnya juga terus bertambah, sehingga kebutuhan pokok maupun kebutuhan tambahan yang harus dipenuhi setiap keluarga juga meningkat. Akibatnya banyak petani-khususnya petani kecil-yang terjerembab dalam lingkaran kemiskinan. Hasil panen yang diperoleh tak mampu memenuhi kebutuhan keluarga hingga panen berikutnya tiba. Pola semacam ini secara konvergentif mengarah pada suatu kondisi dimana petani terancam mengalami keterbatasan modal finansial yang membuat mereka mau tidak mau harus melakukan praktek utang-piutang.

\section{Menjadi petani atau buruh tani}

Secara kasat mata, hal ini menjadi ironi tersendiri bagi rumah tangga petani di Pangumbahan. Boleh jadi hampir seluruh wilayah di Pangumbahan dimanfaatkan pada sektor pertanian, namun hal ini justru tidak mampu menciptakan stabilitas ekonomi setiap rumah tangga petani. Ketimpangan struktur agraria menjadi embrio utama dari persoalan ini. Harus diakui, walaupun beras merupakan sumber nafkah utama petani, namun luas lahan persawahan tergolong sangat minim bila dibandingkan dengan luas lahan perkebunan kelapa. Sebagian besar perkebunan yang ada di Pangumbahan ditanami tanaman tak beranting tersebut. Pangumbahan seolah telah dikepung oleh barisan kelapa yang luasnya mencapai puluhan hektar. Lebih memiriskan lagi, perkebunan kelapa tersebut berstatus HGU. Kondisi ini sudah dimulai sejak lama, yakni pada masa kolonisasi Belanda tahun 1800an. Konon saat ini HGU tersebut dibawah kepemilikan orang Korea yang bahkan penduduk lokal tidak mengenal nama apalagi raut Sang 'Bos besar' itu.

Selain perkebunan yang berstatus HGU, juga terdapat beberapa perkebunan-perkebudan yang cukup luasmeski tidak sebanding dengan perkebunan HGU-milik orang pribumi Ciracas. Perkebunan-perkebunan tersebut selain ditanami kelapa, juga ditanami jati. Para pemilik perkebunan tersebut-walaupun hanya segelintir orangboleh dikatakan menempati kasta lagi, beberapa dari mereka yang berada di kasta menengah tersebut bukan merupakan warga Pangumbahan, tetapi warga desa lain di Kecamatan Ciracas. Struktur yang paling bawah dihuni oleh para petani (khususnya petani kecil).

Lahan yang dimiliki petani selain merupakan lahan rintisan, sebagian juga merupakan warisan orang tua mereka. Tentu saja lahan yang mereka miliki akan didistribusikan lagi kepada anak-anak mereka. Begitulah seterusnya, lahanlahan milik petani dari generasi ke generasi secara perlahan luasnya terus berkurang. Sedangkan perkebunan HGU kelapa tetap luasnya cenderung tetap. Pada proses inilah margin ketimpangan aset lahan pertanian antara perkebunan kelapa dan HGU kelapa makin lama makin renggang. Munculnya para buruh tani boleh jadi merupakan anak kandung dari dialektika ketimpangan tersebut. Mereka yang memiliki lahan pertanian sempit serta mereka yang tidak memiliki lahan pertanian terpaksa menjadi buruh tani. Beberapa dari mereka menggarap lahan milik kerabat terdekat, sedangkan sebagian lainnya mengabdikan dirinya sebagai buruh tani di perkebunan HGU kelapa. Bahkan ketimpangan kepemilikan lahan ini secara eksplisit dapat dilihat dari adanya para petani yang bertumpang sari di kolong-kolong perkebunan HGU kelapa. Dengan demikian, 
kekuatan dasar yang melandasi keketatan dalam struktur komunitas adalah kelangkaan sumberdaya yang relatif kelangkaan sumberdaya non tenaga kerja yang berkaitan dengan kerja. Selama sumberdaya melimpah, tidak ada keharusan untuk mengatur pemakaian diantara pemakainya. Kebutuhan ini muncul hanya apabila sumberdaya menjadi langka dalam orang mulai berlomba ataupun bekerjasama dalam pemakaiannya ( Hayami dan Kikuchi, 1987).

Kondisi ini tentu menjadi rentan akan kemungkinan terjadinya gesekan yang dapat memicu munculnya konflik. Namun bila melihat kondisi yang ada, potensi konflik tersebut agaknya masih berada di wilayah yang abu-abu. Memang, suara-suara risih cukup santer terdengar di lingkungan masyarakat khususnya para petani. Mereka mengeluhkan ulah pihak HGU yang mengharuskan adanya sistem kontrak bagi petani yang bertumpang sari di kawasan perkebunan kelapa. Para petani mengaku diharuskan membayar 20.000 kepada pihak HGU pada setiap tahunnya untuk luas lahan $400 \mathrm{~m} 2$. Tidak hanya itu, mereka juga tidak diperkenankan untuk membeli buah kelapa yang ada di kawasan perkebunan HGU walau hanya beberapa buah saja. Keluhan lainnya yakni mengenai perbaikan akses transportasi di sekitar perkebunan HGU kelapa yang ada di Pangumbahan. Akan tetapi, walaupun kehadiran perkebunan HGU kelapa cenderung ekspolitatif bagi para petani, namun mereka juga menyadari bahwa HGU tersebut juga menjadi sumber alternatif pendapatan mereka. Hal ini membuat para petani dan buruh tani hanya dapat berpasrah dan menjalani dinamika yang ada.

Ketimpangan kepemilikan lahan juga membuat para petani tidak harus monoton pada sektor persawahan saja. Pospos anggaran seperti warung-warung kecil menjadi salah satu alternatif yang digunakan rumah tangga petani untuk dapat bertahan. Sedangkan pada sektor pertanian, para petani menggunakan strategi diversifikasi sumber daya pertanian. Jika dalam keadaan tertentu persawahan tidak mampu menjamin sumber nafkah, merekapun beralih ke komoditi lainnya seperti semangka dan kacang tanah. Beberapa diantara mereka bahkan bertumpang sari di perkebunan HGU kelapa. Situasi ini biasanya terjadi ketika sawah dalam keadaan pasca panen menunggu musim tanam tiba. Berbeda dengan beras, semangka dan kacang tanah dominan merupakan komoditi yang berorientasi pada distribusi (pasar). Para petani yang lebih stabil pemenuhan sumber daya ekonomi rumah tangganya kebanyakan adalah mereka yang mampu menjalankan strategi diversifikasi sumber daya pertanian tersebut secara simultan. Selain memiliki pangan yang mencukupi, mereka juga memiliki aset finansial yang memadai.

\section{Strategi Nafkah Rumah Tangga Masyarakat Desa Pangumbahan}

Dinamika ekonomi di Desa Pangumbahan memaksa rumahtangga untuk mengembangkan strategi nafkah agar tetap bertahan hidup. Strategi nafkah sendiri didefinisikan sebagai segala kegiatan atau keputusan yang diambil anggota rumahtangga untuk bertahan hidup (survival) dan atau membuat hidup lebih baik. Strategi nafkah yang dikembangkan rumahtangga pada umumnya memanfaatkan modal yang dimilikinya yang disebut juga sebagai sumber nafkah yang menurut Scoones (1998: 7) dalam Dharmawan (2001 : 79) terbagi menjadi empat tipe, yaitu : (1) modal alam dalam bentuk sumberdaya alam, (2) modal ekonomi atau finansial yang sangat penting untuk mengejar strategi nafkah, (3) modal manusia, dan (4) modal sosial. Berdasarkan keempat modal, strategi nafkah yang dapat dikembangkan terutama oleh rumahtangga pedesaan terbagi menjadi tiga tipe, yaitu (1) intensifikasi atau diversifikasi pertanian; (2) pola nafkah ganda (keragaman nafkah); dan (3) migrasi.

\section{Intensifikasi dan Diversifikasi Pertanian}

Desa Pangumbahan secara ekologi dikategorikan sebagai desa pesisir dan desa pinggiran hutan.Dengan kata lain, sektor pertanian tanaman pangan relatif terbatas diusahakan di wilayah ini yang sebagian besar berupa daerah kering. Namun demikian, berdasarkan data profil Desa Pangumbahan tahun 2013, 75.14\% masyarakatnya bermatapencaharian di bidang pertanian yang terbagi sebagai petani pemilik lahan $58.25 \%$, petani penggarap tanah $6.58 \%$ dan buruh tani $10.30 \%$. Data tersebut menunjukkan bahwa sektor pertanian masih menjadi sumber nafkah utama bagi warga Desa Pangumbahan.

Keterbatasan modal sumberdaya alam dalam bentuk jenis lahan pertanian yang cenderung lahan kering dan relatif kurang subur, petani melakukan intensifikasi di bidang pertanian. Hal tersebut dilakukan baik pada lahan sawah yang jumlahnya sangat terbatas maupun lahan kebun/lahan kering yang ketersediaanya cukup luas namun kurang dari sisi pengairan. Petani di Dusun Ciburial yang memiliki lahan basah relatif luas melakukan intensifikasi pertanian di lahan basah (sawah) dengan pola tanan dua kali padi dan satu kali palawija dalam satu tahun. Pengolahan lahan cenderung menggunakan teknologi modern mulai dari persiapan tanam dengan bajak mesin dan menggunakan bibit unggul serta pupuk buatan sebagai penyubur tanah. Untuk memaksimalkan hasil, pada musim kemarau lahan sawah yang cenderung kekurangan air dimanfaatkan untuk menanam bawang merah yang memiliki nilai jual lebih tinggi. Pada tahun 2014, petani di Dusun Ciburial juga mencoba menanam kedelai pada saat musim kering sebagai percobaan dalam usaha mendapatkan alternatif pendapatan yang lebih baik selain padi yang cenderung digunakan untuk subsistensi pangan rumahtangga.

Petani lain yang cenderung memiliki lahan kering mengintensifkan lahan dengan jenis tanaman yang bernilai jual tinggi seperti semangka. Tr (39 tahun) yang merupakan ketua kelompok tani Tabah Barokah 
dengan anggota sebanyak 29 orang yang sebagian besar merupakan wargaDusun Waluran, mengusahakan lahan seluas 12 patok atau $4800 \mathrm{~m} 2$. Semangka menjadi pilihan karena harga jual per kilogramnya cukup tinggi yaitu Rp 800. Dengan lahan yang dimiliki perkiraan produksi akan mencapai 10 ton sehingga pendapatan yang diharapkan Rp8.000.000,-. Dengan modal untuk saprotan sebesar Rp3.000.000,- per musim tanam maka keuntungan yang cukup besar diharapkan dapat menghidupi rumahtangganya. Jenis tanaman seperti semangka dan bawang merah yang saat ini banyak dipilih petani sebagai sumber utama penghidupan dari pertanian.

Berdasarkan mini survey yang dilakukan, rata-rata kepemilikan lahan sawah di Desa Pangumbahan seluas 3066,67 m2 dan rata-rata kepemilikan kebun 3233,33 $\mathrm{m} 2$. Dengan luas total lahan yang hanya sekitar 0.6 ha per rumahtangga dan sebagiannya adalah lahan kering, usaha tani yang dijalankan warga Desa Pangumbahan hampir hanya cukup untuk memenuhi kebutuhan subsistensinya. Terlebih lagi jika tidak rumahtangga petani tidak dapat memberikan nilai tambah pada hasil pertanian dengan intensifikasi. Pilihan strategi yang dilakukan didasarkan pada modal sumberdaya alam dan modal sosial yang dimiliki, rumahtangga petani memperluas lahan dengan menyewa lahan perkebunan (HGU kelapa) dan menambah keragaman jenis tanaman seperti padi lahan kering, jagung dan kacang-kacangan yang dapat ditanam dibawah pohon kelapa. Dengan harga sewa lahan sebesar Rp 5000,per pathok $(100 \mathrm{~m} 2)$ per musim, rata-rata rumahtangga tani dapat menambah luas lahan pertanian dari $0,5-1$ hektar. Dengan kata lain rumahtangga tani tidak hanya mengembangkan strategi intensifikasi tetapi juga sekaligus ekstensifikasi dan diversifikasi di bidang pertanian.

\section{Pola Nafkah Ganda}

Keterbatasan sumberdaya lahan memaksa sebagian besar rumahtangga warga Desa Pangumbahan untuk memanfaatkan modal non alam, terutama modal manusia dan modal finansial/ekonomi. Denga modal yang dimilikinya tersebut hampir sebagian besar rumahtangga mengembangkan strategi nafkah pola nafkah ganda. Pola nafkah ganda yang umum dilakukan rumahtangga adalah memanfaatkan semua anggota ruamhatangga pada usia kerja untuk untuk mendapatkan nafkah baik di bidang pertanian maupun non pertanian.

Keberadaan HGU PT. ASABA Land yang sebagian wilayahnya ada di Desa Pangumbahan, selain dimanfaatkan oleh sebagaian warga untuk lahan pertanian, perusahaan juga membuka kesempatan bagi sebagian warga untuk menjadi pekerjanya. Kesempatan lain juga terbuga untuk mengembangnkan ekonomi dari tanaman kelapa dalam pembuatan gula kelapa yang ditekuni oleh sebagian kecil warga desa ini maupun warga dari desa yang lain. Secara tidak langsung hal tersebut membuka peluang ekonomi bagi warga Desa Pangumbahan untuk mendapatkan nafkah dengan membuka warung kelontong, pedagang pengepul maupun jasa ojek (transportasi) serta jenis pekerjaan non pertanian lainnya. Jenis pekerjaan non pertanian semakin berkembang dengan semakin ramainya industri ekowisata yang juga mulai berkembang di wilayah Desa Pangumbahan dan Ujung Genteng.

Kasus pada rumahtangga Yn misalkan, Yn bekerja sebagai mandor pada salah satu area HGU PT ASABA Land yang mendapatkan gaji perbulan selain gaji tambahan dari besarnya pembayaran bagi hasil gula kelapa yang dihasilkan pengrajin gula. Sementara istrinya menjadi pengepul gula dari pengrajin yang ada di Desa Pangumbahan selain membuka warung kelontong yang menjual kebutuhan sehari-hari yang diperlukan pengrajin. Rumahtangga lain memanfaatkan modal finasial dari hasil kerja salah satu anggota rumahtangga di luar negeri untuk membuka usaha penggilingan tepung selain berusaha di pertanian. Begitu juga yang dilakukan oleh beberapa warga yang selain menjadi petani juga bekerja sebagai tukang ojek, penjaga penginapan atau berjualan di lokasi wisata.Jika dikatkan dengan usaha di pertanian, pola nafkah ganda yang dilakukan oleh rumahtangga warga Desa Pangumbahan dapat dikelompok dalam beberapa tipe, yaitu: (a) usaha tani sawah dan/atau ladang dengan bisnis pengolahan hasil pertanian, (b) usaha ladang dengan pengrajin gula kelapa, (c) usaha sawah dan/atau ladang dengan karyawan (buruh tani) HGU ASABA LAND atau perusahaan lainnya termasuk aparat pemerintah, dan (d) usahatani sawah dan/atau ladang dengan perdagangan atau sektor jasa lainnya.

\section{Migrasi}

Strategi nafkah lain yang menjadi pilihan rumahtangga warga Desa Pangumbahan terutama yang masih memiliki anggota keluarga yang relatif muda adalah migrasi. Migrasi terutama bagi perempuan dilakukan dengan menjadi tenaga kerja wanita ke luar negeri seperti Arab Saudi, Taiwan dan Hongkong. Jenis pekerjaan yang dilakukan oleh TKW ini menjadi pembantu rumahtangga. Bagi beberpa rumahtangga, migrasi yang dilakukan salah satu anggotanya memberikan kesempatan untuk memperoleh modal finansial dan mengembangkan menjadi alternatif sumber nafkah lain melalui pembelian tanah, membuka warung atau membeli alat tertentu untuk usaha pengolahan pasca panen atau usaha jasa lainnya. Namun demikian, fenomena migrasi international ini juga memberikan dampak lain terutama terkait hubungan dalam keluarga. Beberapa kasus menunjukkan menjadi penyebab perceraian antara suami dan istri.

Strategi nafkah migrasi juga dilakukan ke kota-kota besar di Jawa Barat dan Jakarta. Sebagian perempuan dari Desa Pangumbahan juga bekerja sebagai pembantu rumah tangga dan sebagian kecilnya menjadi buruh/pegawai perusahaan. Bagi laki-laki, sangat sedikit yang memilih untuk bermigrasi 
terutama jika dalam keluarganya ada orang tua yang menjadi tanggungan atau anak-anak. Pilihan bermigrasi biasanya dilakukan oleh laki-laki yang masih lajang. Sementara bagi yang sudah menikah, berusaha di bidang jasa seperti menjadi tukang ojek masih menjadi prioritas utama.

Pilihan strategi nafkah oleh rumahtangga di Desa Pangumbahan pada umumnya menggabungkan minimal dua dari tiga tipe strategi nafkah. Keterbatasan sumberdaya alam, sumberdaya manusia maupun sumberdaya finasial memaksa rumahtangga untuk mengerahkan segala upaya agar tetap terjamin penghidupannya.

\section{KESIMPULAN}

1. Pertanian padi sawah berdasarkan hasil wawancara dan observasi lapangan belum mampu menopang keadaan sosial ekonomi rumah tangga petani, selain dipengaruhi oleh kepemilikan lahan yang sempit juga belum adanya penggunaan teknologi pertanian modern yang intensif. Akibatnya petani dihadapkan pada pilihan apakah tetap bertahan sebagai petani berlahan sempit atau menjadi buruh tani di HGU atau pelayanan jasa pariwisata. Pola adaptasi ekologi masyarakat Desa Pangumbahan antara lain ditentukan oleh keberadaan HGU perkebunan dan konservasi penyu sebagai pembatas keberadaan pola kebudayaan masyarakat Desa Pangumbahan. pola kebudayaan penduduk desa pangumbahan terbentuk oleh keberadaan perkebunan kelapa semenjak dikuasai penjajah Belanda, kerusakan kawasan pesisir disebabkan munculnya penginapan dan tempat wisata di pesisir pantai, dan cukup tergantung oleh keberadaan pantai dan laut.

2. Keterbatasan sumberdaya alam, manusia dan finansial memaksa rumahtangga untuk melakukan berbagai strategi agar tetap bertahan. Terlebih lagi dengan ancaman dalam hal sumber nafkah pertanian seperti ketidakpastian cuaca yang mengancam produktivitas usaha tani, kurangnya modal untuk usaha non pertanian dan non pertanian, peremajaan lahan perkebunan serta keterbatasan sumberdaya mendorong untuk mencari berbagai alternatif sumber nafkah baik di dalam desa maupun luar desa.

3. Strategi nafkah yang dilakukan rumah tangga masyarakat Desa Pangumbahan menjadi beragam. Dalam satu rumahtangga dapat menerapkan dua atau lebih tipe strategi nafkah.

\section{DAFTAR PUSTAKA}

$\begin{array}{ccc}\text { Desa } & \begin{array}{c}\text { Pangumbahan. } \\ \text { Pangumbahan }\end{array} & \text { 2013. Profil } \\ & & \text { Desa }\end{array}$

Dharmawan, A.H. 2007. 'Sistem Penghidupan dan Nafkah Pedesaan: Pandangan Sosiologi Nafkah (livelihood Sociology) Mahzab Barat dan Mahzab Bogor' dalam Sodality: Jurnal Transdisiplin Sosiologi, Komunikasi dan Ekologi Manusia. Vol. 01, No. 02, Agustus 2007.

. 2001. Farm Household Livelihood Strategies and Socioeconomic Changes in Rural Indonesia. Wissenschafts Verlag Vauk kiel.

Hayami, Yujiro dan Kikuchi, Masao, 191987), Dilema EkonomiDesa; SuatuPendekatanEkonomi Terhadap Perubahan Kelembagaan di Asia (terjemahan), Jakarta, Yayasan Obor Indonesia.

Geertz, Clifford, 1983, Involusi Pertanian (terjemahan), Jakarta, Bhratara Karya Aksara. 